\title{
Erratum to: Classification of Halophyte Community Growth and Its Relationship with Soil Chemical Properties in Saemanguem Reclaimed Land
}

\author{
Myoung-Ho Shin $\cdot$ Chang-Hwan Kim $\cdot$ Min-Kyun Kim
}

Published online: 31 October 2012

(R) Springer-Verlag 2012

Erratum to: J Korean Soc Appl Biol Chem (2012) 55, 599-605

DOI 10.1007/s13765-012-2074-9

One of the authors' affiliations was misprinted.

Min-Kyun Kim is at the Department of Agricultural Biotechnology, Seoul National University in Seoul, Republic of Korea.

The online version of the original article can be found under

doi: $10.1007 / \mathrm{s} 13765-012-2074-9$ 